\title{
SMALL AND MEDIUM ENTERPRISE PRECEPTION OF HALAL CERTIFICATION POST FORMALIZATION OF ISLAMIC CITY BRANDING
}

\author{
Nur Rachmat Arifin ${ }^{1 *}$, Ridan Muhtadi ${ }^{1}$, Sri Herianingrum ${ }^{2}$ \\ *Corresponding author: \\ ${ }^{1}$ Master Islamic Economic Science, Faculty Of Economics and Business, Universitas Airlangga, Surabaya Indonesia, \\ nurrachmatarifin05@gmail.com. \\ ${ }^{2}$ Post Graduate School, Universitas Airlangga, Surabaya Indonesia.
}

\begin{abstract}
SMEs (Small and Medium) are a solution to improve the economic sector and recorded in the Ministry of SMEs increasing from 57.84 percent to 60.34 percent by absorbing labor in the country, but the public and companies do not know much about Halal Certification in Bangkalan, Pamekasan, and Pasuruan, Madura Island that the majority of the people of Islam, past cultural and religious beliefs is still maintained so that its people follow traditional traditions, Madurese in all cities, one of them is Pasuruan, Pasuruan city as the main stopover city for Muslim traders from inside the country and abroad. This research aims to find out how to understand SMEs about halal certification which already has the Islamic City Branding, This research aims to know how to understand SMEs about halal certification that has had the slogan Islamic City Branding, This research uses a descriptive qualitative research method, with sampling techniques using snowball sampling. The primary data sources used in this study were documentation and direct interviews with SMEs in culinary fields in Bangkalan, Pamekasan, and Pasuruan Samples criteria in this study are the SMEs culinary fields in the 3 districts consist of 20 people each in each sub-district, while secondary data sources were obtained from books and journals. The results of this study indicate that as many as 39 or $65 \%$ of informants perceive that halal certificates are not important and only 21 or $35 \%$ of informants who consider halal certificates are important, Many challenges and problems faced in the development of halal lifestyle in Pasuruan and Madura, then the author gave a strategy that must be applied is thorough and answer all the challenges as existing problems, can increase core competencies of SMEs and ultimately increase competitiveness.
\end{abstract}

Keywords: City branding, islam, perception of SMEs, halal

\section{INTRODUCTION}

SMEs (Small and Medium Enterprises) are a solution to improve the regional economic sector and the State, even though they small but with a large enough numbers, they can absorb labors and support the economy, it is proven that SMEs still exist despite the crisis. The contribution of the micro and medium business sector to Gross Domestic Product increased from $57.84 \%$ to $60.34 \%$ in the last five years by absorbing labor in the country also increasing from $96.99 \%$ to $97.22 \%$ in the same period, based on data it has proven that SMEs is an alternative in the expansion of work that overcomes unemployment and poverty.

Based on the data above it is very directly proportional that SMEs are increasing every year and Indonesia which is the majority are Muslim, so according to the regulation that applies every production and distribution business must follow according to Islamic sharia law, which emphasizes Halal and Good, The Indonesian State which has largest muslim population in the world and SMEs that increases every year must know the halal certification issued by MUI (Majlis Ulama Indonesia) so that Muslims in Indonesia can take care of themselves and do not fall into something harmful. Indonesia, which consists of various tribes and cultures including Madura Island that the majority of the people are muslims, cultural beliefs and religions of ancestors are 
still maintained so that the community follows traditionally. Madurese people spread throughout the city, one of which is Pasuruan, located on the coast of East Java in the area of horseshoes, and the city of Pasuruan as the main stopover city for traders from around the country and abroad. Pasuruan, Bangkalan, and Pamekasan Regencies which have the nickname of the City of Sholawat and Dhikr, but the people and companies in these three places do not know much about Halal Certification even though they already have the Formalization of Islamic City Branding Slogan.

"How is the perception of Bangkalan, Pamekasan, and Pasuruan SMEs about the importance of halal certification after the Formalization of City Branding?".

\section{LITERATURE REVIEW}

\section{Perception of SMEs Against Halal Certification}

Yeni Widyastuti argued that perception is a process of making judgments or building impressions about various kinds of things contained in a person's sensory field (Yeni Widyastuti,2014: 34).

According to Sunaryo, perception can be interpreted as the process of receiving stimuli by the five senses that are preceded by attention so that individuals are able to know, interpret, and appreciate about things observed, both inside and outside the individual (Sunaryo, 2004: 94). While Jalaludin Rahmat explained that perception is an experience of an object, event or relationships obtained by concluding information and interpreting messages (Jalaluddin Rahmat, 2003: 51).

According to the RI Law NO. 20 of 2008 SMEs are defined as follows:

1. Micro-enterprises are productive businesses owned by individuals and / or individual business entities that meet the criteria for micro-enterprises as stipulated in the law.

2. Small business is a productive economic enterprise that is independent, carried out by individuals or business entities that are not subsidiaries or not branches of companies owned, controlled, or become part of either directly or indirectly from a medium or large business that meets criteria for small businesses as referred to in the law.

3. Whereas medium-sized business is a productive economic enterprise that is independent, carried out by individuals or business entities that are not subsidiaries or branches of companies that are owned, controlled, or become part of directly or indirectly with small businesses or large businesses with net assets or annual sales results as stipulated in the law (Rachmawan Budiarto, $2015: 3$ ).

According to Tulus Tambunan, SMEs are stand-alone productive business units, carried out by individuals or business entities in all economic sectors (Tulus T Tambunan, 2012:11). It can be concluded that the perception of SMEs is a productive form of business that is managed by both individuals and business entities, which are expected to be able to make the economy develop and be able to recognize the stimulation by the five senses.

In today's modern era, business in the field of production has experienced a very significant increase along with the development of science and technology. The increase in production, in addition to making it easier for the public to consume it, turned out to raise concerns about product quality if viewed from the halal aspect. How can consumer protection be realized if the halal aspect as a prerequisite does not get attention? 
The effort to provide a product's security to a society is an important part of the consumer protection law. To realize that effort, it is necessary to have a concept that can be used to determine the halal-haram measure. In the Islamic perspective, the provision of halal haram is the right of Allah SWT created through the practice of His (the Qur'an and the Sunnah).

"Say" who has forbidden the jewelry of Allah that he has issued for his slaves and (who is the forbidden) good rezqi? "Say:" It is for those who believe in the life of the world, especially on the Day of Resurrection, thus we explain those verses to those who know. "(Q.S. Al-A 'raf [7]: 32).

Allah SWT. Said to refute the opinion of people who forbid something from food or drink or clothing according to their own will without any shari'ah basis from Allah. O Muhammad, say to the idolaters who forbid everything they forbid in their own opinion which is broken and according to their own making (Abul Fida Isma'il Ibnu Kasir Ad-Dimasyqi, 2010: 292).

Halal certificate is a written fatwa from MUI which states the halalness of a product in accordance with Islamic law. This halal certificate is a condition for obtaining permission to include halal labels on product packaging from authorized government agencies. Procurement of halal certification in food products, medicines, cosmetics and other products actually aims to provide certainty of halal status of a product, so as to reassure the Muslim consumers. However, ignorance often makes the company lack awareness to register to obtain halal certificates (Burhanuddin,2011: 143).

The MUI halal certificate holder is responsible for maintaining the halalness of the products it produces, and this certificate cannot be transferred. The validity period of a halal certificate is 2 years, which can then be renewed. This provision is intended to maintain the consistency of producers during the enactment of the certificate. Certificates that have expired, including photocopies, may not be used or installed for certain purposes. Whereas for meat exported halal certificates are given for each packing.

"Then eat the lawful again from the provision that God has given you, and thank God for the blessing, if you only worship Him.» (Surat an-Nahl [16]: 114).

For Muslims, consuming halal and good (thayyib) is a manifestation of devotion to Allah SWT. One thing that is very important to be believed by every Muslim is that anything that Allah SWT has allowed in the form of food, there is enough for them (humans) not to consume unclean food. As a result of consuming unclean food in addition to being harmful to the health of the body, also to the perpetrators of the threat of hell (Burhanuddin,2011: 143).

\section{METHOD}

To be able to answer the problems in the perception of SMEs in understanding halal certification by the MUI, certain steps need to be taken. Qualitative research is descriptive, snowball sampling technique as one of the reliable sampling techniques to obtain data from respondents in order to answer specific field research problems, but based on a specific purpose for several reasons, for example the reasons for time, effort, and funds are not able to take 
samples big and far. Samples criteria in this study are the SMEs culinary fields in the 3 districts consist of 20 people in each sub-district.

The approach in this study uses an anthropological approach that is examining humans both physically and non-physically (anthropological approach to understanding religion (in this study about halal certificates) on halal certification, while the articles used as references and additional discourses are articles, magazines, journals, books, and internet websites. This research is a field research, namely a research whose main data is explored through observations and data sources in the field (an-Na'im,1993:02). The research is carried out directly on the object, in other words the researcher is in the field or directly in an environment that has problems or that will be repaired or refined.

\section{RESULT}

\section{Islamic City Branding Petterns Against Perceptions Of Halal Certification}

Sharia comes from the word syari'a, meaning taking a path that gives access to the source. The term sharia also means the way of life. The root of the word Sharia and its derivatives in a sense commonly used only in the five verses of the Qur'an (Qur'an 5:48, 7: 163, 42:13, 42:31, and 45:18). In general, sharia means "the Islamic way of life which is determined based on divine revelation". So, it does not only cover legal and jurisprudential issues, but also practices of ritual worship, theology, ethics, personal health and good manners (Santoso,2003:85). Therefore, the sources of sharia are the Qur'an, Hadith, the science of fiqh, kalam and various human ijtihad. Thus, sharia not only understood as a single-dimensional rule, but it is more of a religious message that is constantly evolving and requires continuous innovation.

In this case the people of Bangkalan, Pamekasan, and Pasuruan have a long historical background in making Islam their life guide. Madurese and Pasuruan people are very submissive to the teachings of Islam and they obey and pay attention to the fatwa of the ulama, because ulama is the heir of the Prophet SAW. The appreciation of the teachings of Islam in the long term gave birth to Madurese culture which is reflected in indigenous life. Tradition was born from the reflection of the scholars, then practiced, developed, and preserved, then concluded to be "customary law in the middle of the government and Sharia law is in the hands of scholars". This expression is a reflection of the realization of Islamic law in the practice of daily life for the Madurese people.

1. Understanding of informants about halal certificates

\section{a. The informant does have an understanding of halal certificates}

From the results of interviews with all informants, there were several informants who said that the halal certification was food that had been reviewed by MUI. Some of them are:

“...sertifikasi halal itu merupakan makanan yang sudah dicek oleh BPOM”.

"... halal certification is food that has been checked by BPOM".

As stated by Mukti, the halal certification is a product that has been inspected or checked by National Agency of Drug and Food Control (BPOM). The same thing was also conveyed by Reso as follows: 
“...sertifikasi halal itu adalah makanan yang diperiksa oleh MUI”.

"... halal certification is food that is examined by the MUI".

As stated by the salted egg businessman, the informant also believes that the halal certification, namely halal certificate, is a product that has been examined by MUI.

From 60 informants (culinary SMEs in Bangkalan, Pamekasan, and Pasuruan) who argued that the halal certification was food that had been examined (checked, surveyed, researched) by the DFC (MUI or in charge) is as much as 12 or $20 \%$ of informants, informants who argued whereas the halal certification is a halal guarantee from the MUI, a letter from the MUI, or published by the MUI as much as 18 or $30 \%$ of informants, while the informant who believes that halal certification is a halal guarantee, halal award, or has been checked for halal is 15 or $25 \%$ informant. So informants who have knowledge of halal certification are 45 or $75 \%$ of informants, consists of Bangkalan 13 people or $21,67 \%$, Pamekasan 15 people or $25 \%$, Pasuruan 17 people or $28,33 \%$.

\section{b. The informant does not have an understanding of halal certificates}

From the interviews with all informants, there were several informants who did not know what halal certification was. Among them are:

“...tak taoh, jek yak sertifikatah halal yak gun setiah guruh ngeding been yak atanyah riah"

"I don't know, because I just heard the halal certificate now and you are asking about i)".

As stated by M. Zaini, there are still producers who still do not know about halal certification. The same thing was also conveyed by Herani as follows:

“...tidak tahu sama sekali”.

"...I don't know at all”.

As stated by the businessman of this restaurant, the informant's knowledge still does not know what is halal certification even though halal certification is needed by producers to increase their competitiveness or market share, and informants who argue that this requires guidance or socialization from the party in charge in this case the NADFC and IUC of Bangkalan, Pamekasan dan Pasuruan.

From as many as 60 informants from the culinary SMEs in Bangkalan, Pamekasan and Pasuruan who claimed they still did not understand what halal certification was and some were of the opinion that lack of understanding about halal certification was 15 or $25 \%$ of informants, consists of Bangkalan 7 people or 11,67\%, Pamekasan people 5 or $8,33 \%$, Pasuruan 3 people or $5 \%$.

\begin{tabular}{|c|c|c|c|}
\hline \multirow{2}{*}{ No } & \multirow{2}{*}{ City Name } & \multicolumn{2}{|c|}{ Understanding Percentage } \\
\cline { 3 - 4 } & & Understanding & Doest not Understanding \\
\hline 01 & Bangkalan & $21,67 \%$ & $11,67 \%$ \\
\hline 02 & Pamekasan & $25 \%$ & $8,33 \%$ \\
\hline 03 & Pasuruan & $28,33 \%$ & $5 \%$ \\
\hline
\end{tabular}




\section{Awareness of informants about the interest in arranging halal certification}

\section{a. Informants who are interested in taking care of halal certification}

From the results of interviews with all informants, there were several informants who were interested in taking care of the halal certification. Among them are:

“...iya, saya berminat untuk mengurusnya”.

“...Yes, I'm interested taking care of it”.

As stated by Mr. Tomo, the informants are interested in arranging halal certification to improve their competitiveness. The same thing was conveyed by $\mathrm{Mr}$. Karnadi as follows:

“...sebenarnya saya berminat mengurusnya, tapi sepetinya biayanya mahal”.

“...actually I'm interested in taking care of it, but it seems expensive”.

As stated by the tape entrepreneur, informants are interested in taking care of it, but are constrained by expensive management fees. There were also informants who had taken care of the halal certification to the MUI, including:

"... I have taken care of it, Inshaallah, next year I will take care of it again".

As stated by Mr. Mukti, that the informant has taken care of it, and the informant is interested in taking care of it again if the current halal certificate has expired or expired.

Of the 60 informants (culinary UMKM in Bangkalan, Pamekasan, and Pasuruan) who argued that they were interested in arranging the halal certification as many as 15 or $25 \%$ of the informants. While those who have taken care of halal certification are 6 or $10 \%$ of informants.

So it can be concluded that informants who are interested in taking care of halal certificates are 21 or $35 \%$ of informants, consists of Bangkalan 5 people or $8,33 \%$, Pamekasan 6 people or $10 \%$, Pasuruan 10 people or $16,67 \%$.

\section{b. Informants who are not interested in taking care of halal certification}

Not all informants are interested in taking care of the halal certification, but there are still some informants who are not interested in taking care of it, including:

“...tidak, soalnya pelanggan saya sudah percaya terhadap bakso saya."

“... No, because my customers have believed in my meatballs."

As stated by Mr. Samo, the informants are not interested in taking care of halal certification because customers or consumers do not pay attention to the halal they eat. The same thing was conveyed by Mr. Karnadi as follows:

“...tidak, karena sepertinya cara mengurus ke MUI sulit”.

"... no, because it seems like the way to take care of the MUI is difficult".

As stated by the dumpling businessman, the informants were not interested because they considered that the matter of handling halal certification was very difficult. 
Of the 60 informants (culinary SMEs in Bangkalan, Pamekasan, and Pasuruan) who argued that they were not interested in arranging the halal certification as many as 35 or $65 \%$ of the informants, consists of Bangkalan 15 people or 25,\%, Pamekasan 14 people or $23,33 \%$, Pasuruan 10 people or $16,67 \%$.

\begin{tabular}{|c|c|c|c|}
\hline \multirow{2}{*}{ No } & \multirow{2}{*}{ City Name } & \multicolumn{2}{|c|}{ Awareness Percentage } \\
\cline { 3 - 4 } & & conscious & Does not unconscious \\
\hline 01 & Bangkalan & $8,33 \%$ & $25 \%$ \\
\hline 02 & Pamekasan & $10 \%$ & $23,33 \%$ \\
\hline 03 & Pasuruan & $16,67 \%$ & $16,67 \%$ \\
\hline
\end{tabular}

The problem regarding the enforcement of Islamic City Branding especially in Madura has indeed become a very echoing in the ears. At least the spirit to go towards a change in the implementation of Islamic law has been embedded in the local community. Regarding this matter, Topo Santoso in his book revealed some descriptions about the implementation of Islamic Sharia in several regions. In the book explained, that for Muslims there is no other choice but to believe that carrying out Islamic law is a part of doing din (religion) faithfully. If now many expressed the desire to uphold Islamic law in some places of birth it is not a sign of euphoria of democracy and freedom. It was born because of the awareness of Muslims on Western law which originated from the mind of human thought with Islamic law which originated from valid life references, namely the Qur'an and Sunnah. Thus, Islamic law is seen as the most appropriate with a sense of justice. Islamic Sharia is seen as the most able to fulfill the five basic human needs (maqashidusy-syari' ah al khamsah) which is protecting the din (religion), soul, wealth, mind, and descent.

\section{DISCUSSION}

Strong spirit for the Madurese people to impose Regional Autonomy on the image of an Islamic city in which it provides a vast area to manage its area in accordance with local Islamic treasures. Because Islamic Sharia in Madura and Pasuruan is understood by its people not only in the legal and judicial aspects, but includes various other fields, such as Social, Cultural, Governance.

Many challenges and problems faced in the development of halal lifestyles in Indonesia and also in Madura. The problems that arose among others were the low understanding of the community towards the Halal Consensus. When the growth of a massive halal lifestyle in this country, the selection factor of the cultivation of halal lifestyle knowledge from an early age as a pilot project in terms of supporting the lifestyle community according to religious guidelines. Therefore, this is felt to be quite prospective to make SMEs owners as the starting place to develop halal-minded human resources in each product with remain quality.

Based on the condition of halal product certification conditions in Bangkalan, Pamekasan, and Pasuruan a strategy is needed to improve SMEs in Madura and Pasuruan who are aware of halal certification. This applied strategy must be comprehensive and answer all challenges and problems that exist. In essence this strategy can increase core competencies from SMEs owners and ultimately improve competitiveness, including: 


\section{a. Local Government Support with the implementation of Islamic City Branding.}

Local government support for the development of halal lifestyles in Bangkalan, Pamekasan, and Pasuruan is still developing slowly. There are still a lot of focus on products from large companies. This is based on the authority which is the choice that is owned by the local government in Madura as an autonomous region as stipulated in the Indonesian Law No. 23 of 2014 concerning Regional Government (abbreviated as Regional Government Law). In this Regional Government Law, there are functions which are the authority of regional / municipal governments that are optional, namely in Article 14 paragraph 2 of the Regional Government Law, which reads (Ikhwan,2013:72): "Regional Government Affairs that are optional include government affairs that are real and potentially to improve the welfare of the community in accordance with the conditions, peculiarities, and superior potential of the region concerned." So it needs a Legislation Regulation from the local government regarding the development of Islamic economic education or Islamic-based economic education at the level of primary and secondary education on the suitability of religious local wisdom.

\section{b. Regional Regulatory Model}

When speaking to the Regional Government, there has been a very fundamental change since the adoption of Indonesian Law No. 32 of 2004 which was later refined into Indonesian Law No. 23 of 2014 concerning Regional Government. The fundamental thing in change lies in the relationship between the Central Government and the Regional Government that is broad, real, and responsible. Consequently the local government must really take advantage of this situation by optimizing the various potentials and local wisdom that exist. While in the meantime there are several Sharia Regulations and formalization of Islamic Sharia demands which are also realized through local government policies in the form of Decrees, Instruction and Circular of Mayors. Which is at least in conformity with the application of Sharia Regulations on halal lifestyles discussed by the authors which include:

i. Pamekasan Madura Regency: Pamekasan Regent Circular Number 450/2002 concerning the Application and Treatment of Islamic Sharia in its entirety (Suharso,2006:231)

The above is in the form of a Sharia Regional Regulation which can be a reference for local governments in Madura to implement Islamic Shari'a Regional Regulations in an effort to create a massive halal lifestyle of society.

\section{c. Adding Value Added to SMEs in Madura and Pasuruan about Halal Certification.}

Value added that needs to be added to SMEs players can be done by educating to better understand Islam in the economic field. In addition, it will strengthen the economic foundation of human resources with character and good character. So that prosperity will be created evenly.

Of course the application of Islamic city branding is the first step in the establishment of this type of Regional Sharia Law still faces some latent obstacles. For example, all elements in Bangkalan, Pamekasan, and Pasuruan must be synergized, especially the Government, Academics and Practitioners in the SMEs sector, industry owners and sharia economic businesses. Because increasing halal lifestyles will increase the potential of new markets 
that remain untouched especially in Bangkalan, Pamekasan, and Pasuruan, this increase also signifies the magnitude of the Halal Industry's influence on the economy as a whole. Industries with a large market share will also have a large market demand, this is where the human resource needs of this workforce can be fulfilled if the halal certification in Madura and Pasuruan is in accordance with mu'amalah Islamiyah.

Increasing Islamic market share will make the Indonesian economy more inclusive due to equitable growth. Moreover, this will improve the economic foundations of regions in Indonesia which will lead to increased global competitiveness. Wallahua'lam bisshowab.

\section{CONCLUSION}

Islamic City Branding that is part of Bangkalan, Pamekasan, and Pasuruan slogan cannot be implemented according to Islamic law as a way of life for the Madura and Pasuruan people, especially in halal product certification for industry owners and SMEs because there are still many people and industry owners in SMEs who do not understand the importance of Halal certification, it requires synergic support from all elements in Madura and Pasuruan, especially the Government, Academics and Practitioners, SMEs owners, industry ownders and sharia economic businesses, to promote understanding of Halal Certification. The time of the consumer will slowly consume halal-certified goods, the understanding of halal certification for SMEs should be in a different, considering the number of Muslim populations to be a majority in Indonesia, then the government must provide a process for making halal certificates easily and cheaply

\section{REFERENCES}

Abdullah Ahmed an-Na'im. (1993) Al-Qur'an, Syari'ah, dan HAM: Kini dan di Masa Depan, Jurnal Islamika No 02.

Burhanuddin. (2011). Pemikiran Hukum Perlindungan Konsumen dun Setifikasi Halal (Malang: UIN Maliki Press.

Departemen Agama RI. Al-Qur'an Mushaf......

Ibnu Kasir Ad-Dimasyqi, Abul Fida Isma'il. (2010). Tafsir Ihnu Kasir, Bandung: Sinar Baru Algensindo.

Jalaluddin Rahmat. (2003). Psikologi Komunikasi, Bandung: Remaja Rosdakarya, .

Marijul ikhwan dkk. (2013). Pengaturan Hukum Pengetahuan Tradisional Sebagai Upaya Perlindungan Kearifan Lokal Madura Oleh DPRD Bangkalan, Jurnal Yustisia edisi 85.

Pudjo Suharso. (2016). Pro Kontra Implementasi Perda Syariah (Tinjauan Elemen Masyarakat), Jurnal Al=Mawarid Edisi 16.

Rachmawan Budiarto dkk. (2015). Pengembangan UMKM Antara Konseptul Dan Pengalaman Praktis, Yogyakarta: Gadjah Mada University Press. 
Sunaryo. (2004). Psikologi Untuk Keperawatan, Jakarta: EGC.

Tambunan, Tulus T. (2012).Usaha Mikro Kecil dan Menengah di Indonesia: Isu-isu Penting, cet. ke-1, Jakarta: LP3ES.

Topo Santoso. (2003). Membumikan Hukum Pidana Islam, Yogyakarta: Gema Insani Press.

Widyastuti, Yeni. (2014). Psikologi Sosial, cet. ke-1,Yogyakarta: Graha Ilmu. 